\title{
Genetic parameters for test-day yield of milk, fat and protein in buffaloes estimated by random regression models
}

\author{
Rúsbel R. Aspilcueta-Borquis ${ }^{1}$, Francisco R. Araujo Neto ${ }^{1}$, Fernando Baldi ${ }^{1}$, Daniel J. A. Santos ${ }^{1}$, \\ Lucia G. Albuquerque ${ }^{1,2}$ and Humberto Tonhati ${ }^{1,2 *}$ \\ ${ }^{1}$ Department of Animal Science, São Paulo State University (FCAV/UNESP), Jaboticabal 14884 900, SP, Brazil \\ ${ }^{2}$ Conselho Nacional de Desenvolvimento Científico e Tecnologico (CNPq) and Instituto Nacional de Ciência e Tecnologia - Ciência Animal \\ (INCT - CA), Viçosa 36570 000, MG, Brazil
}

Received 7 December 2011; accepted for publication 2 February 2012; first published online 23 March 2012

\begin{abstract}
The test-day yields of milk, fat and protein were analysed from 1433 first lactations of buffaloes of the Murrah breed, daughters of 113 sires from 12 herds in the state of São Paulo, Brazil, born between 1985 and 2007. For the test-day yields, 10 monthly classes of lactation days were considered. The contemporary groups were defined as the herd-year-month of the test day. Random additive genetic, permanent environmental and residual effects were included in the model. The fixed effects considered were the contemporary group, number of milkings (1 or 2 milkings), linear and quadratic effects of the covariable cow age at calving and the mean lactation curve of the population (modelled by third-order Legendre orthogonal polynomials). The random additive genetic and permanent environmental effects were estimated by means of regression on third- to sixth-order Legendre orthogonal polynomials. The residual variances were modelled with a homogenous structure and various heterogeneous classes. According to the likelihood-ratio test, the best model for milk and fat production was that with four residual variance classes, while a third-order Legendre polynomial was best for the additive genetic effect for milk and fat yield, a fourth-order polynomial was best for the permanent environmental effect for milk production and a fifth-order polynomial was best for fat production. For protein yield, the best model was that with three residual variance classes and thirdand fourth-order Legendre polynomials were best for the additive genetic and permanent environmental effects, respectively. The heritability estimates for the characteristics analysed were moderate, varying from $0 \cdot 16 \pm 0 \cdot 05$ to $0 \cdot 29 \pm 0 \cdot 05$ for milk yield, $0 \cdot 20 \pm 0 \cdot 05$ to $0 \cdot 30 \pm 0 \cdot 08$ for fat yield and $0 \cdot 18 \pm 0 \cdot 06$ to $0 \cdot 27 \pm 0 \cdot 08$ for protein yield. The estimates of the genetic correlations between the tests varied from $0 \cdot 18 \pm 0 \cdot 120$ to $0 \cdot 99 \pm 0 \cdot 002$; from $0 \cdot 44 \pm 0 \cdot 080$ to $0 \cdot 99 \pm 0 \cdot 004$; and from $0 \cdot 41 \pm 0 \cdot 080$ to $0.99 \pm 0.004$, for milk, fat and protein production, respectively, indicating that whatever the selection criterion used, indirect genetic gains can be expected throughout the lactation curve.
\end{abstract}

Keywords: Covariance functions, heritability, Legendre polynomials.

Buffalo milk is mainly used to make cheeses, especially mozzarella. As with any commercially produced milk, the economic value depends not only on the quantity produced, but also on the composition, mainly the fat and protein contents (Seno et al. 2007). In Brazil, as a consequence of improvement in management, infrastructure and feeding practices on buffalo farms, over the last two decades the buffalo milk production per lactation has increased considerably (Tonhati et al. 1996; Malhado et al. 2007; Aspilcueta et al. 2010a). To date, the genetic evaluation

*For correspondence; e-mail: tonhati@fcav.unesp.br for milking buffaloes is carried out for total milk yield using a repeatability model. This model assumes that genetic and phenotypic variances are constant along the lactation and the lactation curve is equal or the same for all the animals. Moreover, short-length lactations are common in buffaloes, and thus, lactation records must be extended to be included in a genetic evaluation. Alternatively, the production of milk and its constituents by dairy buffaloes can be represented by points that are related to the lactation trajectory, enabling their evaluation by random regression models (RRMs).

RRMs allow the fitting of random lactation curves to each individual, expressed as deviations from a mean curve of the population or groups of individuals. In fitting a RRM, a structure of covariances among the observations is implicitly 
assumed, determined by the covariances of the regression coefficients, so that it can be defined as a covariance function. The implementation of RRMs to estimate genetic parameters for characteristics of the yield of milk and its constituents is widespread in the dairy industry (Schaeffer \& Jamrozik, 2008).

Estimates of genetic parameters obtained by using random regression models for dairy buffalo traits are scarce in the literature and those that do exist only consider milk output (Breda et al. 2010; Sesana et al. 2010). These authors report heritability estimates of milk yield ranging from 0.19 to 0.54 during lactation. However, there are no reports of genetic parameter estimates for the constituents of buffalo milk using RRMs. In contrast, in the case of dairy cattle, such estimates of the production of milk and its constituents have been published for a number of breeds (Liu et al. 2000; Jakobsen et al. 2002a, b; De Roos et al. 2004; Silvestre et al. 2005).

Therefore, the objective of this work was to estimate covariance functions for the additive genetic and permanent environmental effects, and subsequently the genetic parameters, for yield of milk, fat and proteins, through the use of random regression models with Legendre polynomials, considering different residual variance structures.

\section{Material and Methods}

We analysed test-day results of milk, fat and protein production from 1433 first lactations of Murrah buffaloes, with ages from 24 to 48 months and born between 1985 and 2007, daughters of 113 sires, from 12 herds located in the state of São Paulo, Brazil. The milk yields records were obtained starting on the fifth day after calving and were truncated at 305 days of lactation, since only $12 \%$ of females had a lactation length greater than this period. Only cows that had their first test-day record before $45 \mathrm{~d}$ after calving were considered in the analyses.

The test-day productions were considered in monthly lactation classes, varying from 1 to 10 classes, and included animals with at least four tests. The contemporary groups were defined as herd-year-month of milk test, with the restriction that each group had to contain at least four animals. After data consistency, the descriptive statistics for milk, fat and protein yield along the lactation (first lactation) are shown in Table 1. A pedigree file containing 10088 animals was used in all the analyses.

The characteristics of milk, fat and protein production were analysed by means of single-trait random regression models. All the models included additive genetic, permanent environmental and residual effects of the animal. The fixed effects considered were the contemporary group, number of milkings ( 1 or 2 daily), the linear and quadratic effects of the covariable cow age at calving and the average lactation curve of the population, modelled by a third-order orthogonal polynomial. In matrix form, the model can be represented by:

$y=X b+Z a+W a p+e$ where $y=$ vector of observations; $b=$ fixed-effects vector (contemporary group, number of milkings; covariable age of the cow at calving and mean population curve); $a=$ vector of solutions for the random additive genetic regression coefficients; $a p=$ vector of solutions for the random permanent environmental regression coefficients; $e=$ vector of the different residuals; and $\mathrm{X}, \mathrm{Z}, \mathrm{W}=$ incidence matrices for the fixed effects and random additive genetic and permanent environmental effects, respectively. The dimension of the vector $a$ is $k_{a} N_{a}$ coefficients, where $k_{a}$ represents the order of the polynomial and $N_{a}$ the number of animals in the numerator relationship matrix. The vector ap has dimension of $k_{a p} \times N_{d}$ coefficients, where $k_{a p}$ represents the order of the polynomial and $N_{d}$, the number of animals with phenotypic records.

In the analysis we assumed that the records are distributed with mean $X \beta$, and for the random additive genetic, permanent environmental and residual effects we considered:

$E\left[\begin{array}{c}a \\ a p \\ e\end{array}\right] \sim N\left(\left[\begin{array}{l}0 \\ 0 \\ 0\end{array}\right],\left[\begin{array}{ccc}K_{a} \otimes A & 0 & 0 \\ 0 & K_{a p} \otimes I_{N d} & 0 \\ 0 & 0 & R\end{array}\right]\right)$

where: $K_{a}$ and $K_{a p}$ are the matrices of covariances between the random additive genetic regression and permanent environmental coefficients, respectively; $A$ is the numerator relationship matrix among the individuals; $I_{N d}$ is the identity matrix with dimension $N_{d} ; \otimes$ is the Kroneker product between the matrices; and $R$ represents a diagonal block matrix containing the residual variances. We assumed independence of the residuals.

The random additive genetic and permanent environmental effects were modelled by third- to sixth-order Legendre polynomials. Residual variances were modelled using a step function with 1, $3(1-3,4-8,9-10), 4(1,2-3$, $4-8,9-10)$ or 10 classes for milk production, and with 1,4 $(1,2-6,7-8,9-10), 6(1,2,3-4,5-6,7-8,9-10)$ or 10 classes for fat production, and with $1,3(1,2-6,7-10)$ or 10 classes for protein production.

The citation of the RRMs follows the pattern: $L E G k_{a} \cdot k_{a p} r$, referring to the order of the covariance function for the additive genetic effects $\left(k_{a}\right)$, the permanent environmental effects $\left(k_{a p}\right)$ and the residual variances structure $(r)$. For example, the LEG3,4_3 model denotes an analysis fitting a third- and fourth-order Legendre polynomial for the additive genetic and the permanent environmental effects, respectively, and the residual variances modelled with a step function with 3 classes.

The covariances functions were estimated by the restricted maximum likelihood method, employing the WOMBAT statistical program (Meyer, 2006).

The different models were compared by the logarithm of the likelihood function ( $\log L$ ), the likelihood ratio test (LRT) at $1 \%$ probability, the restricted maximum likelihood forms of the Akaike information criterion (AIC) and Bayesian information criterion (BIC) of Schwarz and by examining the variances and correlations 
Table 1. Description of the production data $(\mathrm{kg})$ of milk per month, fat and protein yield during the first lactation

\begin{tabular}{|c|c|c|c|c|c|c|c|c|c|c|c|}
\hline \multirow[b]{2}{*}{$\mathrm{C}+$} & \multirow[b]{2}{*}{$\mathrm{N}$} & \multicolumn{3}{|c|}{ Milk } & \multirow[b]{2}{*}{$\mathrm{N}$} & \multicolumn{3}{|c|}{ Fat } & \multicolumn{3}{|c|}{ Protein } \\
\hline & & Mean & SD & $C V, \%+$ & & Mean & SD & $C V, \%$ & Mean & SD & $C V, \%$ \\
\hline 1 & 725 & $8 \cdot 24$ & $3 \cdot 14$ & $38 \cdot 25$ & 475 & $0 \cdot 40$ & $0 \cdot 15$ & $36 \cdot 90$ & $0 \cdot 23$ & 0.09 & $36 \cdot 75$ \\
\hline 2 & 1352 & $8 \cdot 87$ & $3 \cdot 36$ & $38 \cdot 41$ & 894 & $0 \cdot 47$ & $0 \cdot 15$ & $30 \cdot 95$ & $0 \cdot 26$ & 0.08 & $30 \cdot 94$ \\
\hline 3 & 1387 & $8 \cdot 32$ & $3 \cdot 23$ & $39 \cdot 24$ & 854 & $0 \cdot 49$ & $0 \cdot 15$ & $30 \cdot 78$ & $0 \cdot 27$ & 0.08 & $30 \cdot 33$ \\
\hline 4 & 1348 & 7.96 & $2 \cdot 98$ & $37 \cdot 35$ & 883 & $0 \cdot 47$ & $0 \cdot 14$ & $30 \cdot 38$ & $0 \cdot 26$ & 0.08 & $30 \cdot 33$ \\
\hline 5 & 1322 & $7 \cdot 78$ & $2 \cdot 87$ & $37 \cdot 61$ & 879 & $0 \cdot 43$ & $0 \cdot 15$ & $33 \cdot 74$ & $0 \cdot 25$ & 0.08 & $33 \cdot 58$ \\
\hline 6 & 1301 & $7 \cdot 06$ & $2 \cdot 63$ & $37 \cdot 53$ & 800 & $0 \cdot 40$ & $0 \cdot 15$ & $37 \cdot 29$ & $0 \cdot 24$ & 0.09 & $37 \cdot 33$ \\
\hline 7 & 1288 & $6 \cdot 68$ & $2 \cdot 54$ & $38 \cdot 14$ & 786 & $0 \cdot 38$ & $0 \cdot 14$ & $37 \cdot 07$ & $0 \cdot 24$ & 0.09 & $37 \cdot 08$ \\
\hline 8 & 1173 & $6 \cdot 02$ & $2 \cdot 41$ & $40 \cdot 21$ & 667 & $0 \cdot 34$ & $0 \cdot 13$ & $38 \cdot 60$ & $0 \cdot 22$ & 0.09 & 38.59 \\
\hline 9 & 966 & $5 \cdot 59$ & $2 \cdot 24$ & $40 \cdot 23$ & 466 & $0 \cdot 31$ & $0 \cdot 13$ & $39 \cdot 85$ & $0 \cdot 22$ & 0.09 & 39.93 \\
\hline 10 & 807 & 4.90 & 1.98 & $40 \cdot 45$ & 204 & $0 \cdot 30$ & $0 \cdot 12$ & $38 \cdot 41$ & $0 \cdot 22$ & $0 \cdot 08$ & 38.05 \\
\hline
\end{tabular}

+C: monthly test; $\mathrm{N}$ : number of observations; CV: coefficients of variation

Table 2. Number of estimated parameters (N), log likelihood function (Log L), Akaike's information criterion (AIC), Schwarz Bayesian information criterion (BIC) and likelihood ratio test (LRT) for the models used comparing the number of classes for the residual variance of milk, fat and protein yields

\begin{tabular}{|c|c|c|c|c|c|}
\hline Modelt & $N$ & $\log L$ & $\mathrm{AIC}$ & $\mathrm{BIC}$ & LRT‡ \\
\hline $\begin{array}{l}\text { Milk } \\
\text { (1) LEG3,3_1 } \\
\text { (2) LEG3,3_3 } \\
\text { (3) LEG3,3_4 } \\
\text { (4) LEG3,3_10 }\end{array}$ & $\begin{array}{l}13 \\
15 \\
16 \\
22\end{array}$ & $\begin{array}{l}-8071 \cdot 06 \\
-8037 \cdot 01 \\
-8027 \cdot 61 \\
-8018 \cdot 98\end{array}$ & $\begin{array}{l}16168 \cdot 12 \\
16104 \cdot 01 \\
16087 \cdot 22 \\
16081 \cdot 96\end{array}$ & $\begin{array}{l}16262 \cdot 20 \\
16212 \cdot 57 \\
16203 \cdot 07 \\
16241 \cdot 17\end{array}$ & $\begin{array}{l}(2-1) 34 \cdot 05^{* *} \\
(3-2) 9 \cdot 40^{* *} \\
(4-3) 8 \cdot 63^{\text {n.s }} \\
-\end{array}$ \\
\hline $\begin{array}{l}\text { Fat } \\
\text { (1) LEG3,3_1 } \\
\text { (2) LEG3,3_4 } \\
\text { (3) LEG3,3_6 } \\
\text { (4) LEG3,3_10 }\end{array}$ & $\begin{array}{l}13 \\
16 \\
18 \\
22\end{array}$ & $\begin{array}{c}19458 \cdot 23 \\
19570 \cdot 88 \\
19575 \cdot 07 \\
19577 \cdot 24\end{array}$ & $\begin{array}{l}-38890 \cdot 46 \\
-39109 \cdot 76 \\
-39114 \cdot 15 \\
-39110 \cdot 48\end{array}$ & $\begin{array}{l}-38796 \cdot 72 \\
-38994 \cdot 38 \\
-38984 \cdot 35 \\
-39154 \cdot 48\end{array}$ & $\begin{array}{l}(2-1) 112 \cdot 65^{* *} \\
(3-2) 4 \cdot 19^{\text {n.s }} \\
(4-3) 2 \cdot 17^{\text {n.s }} \\
-\end{array}$ \\
\hline $\begin{array}{l}\text { Protein } \\
\text { (1) LEG3,3_1 } \\
\text { (2) LEG3,3_3 } \\
\text { (3) LEG3,3_10 }\end{array}$ & $\begin{array}{l}13 \\
15 \\
22\end{array}$ & $\begin{array}{l}24077 \cdot 13 \\
24159 \cdot 43 \\
24174 \cdot 95\end{array}$ & $\begin{array}{l}-48128 \cdot 25 \\
-48288 \cdot 87 \\
-48305 \cdot 89\end{array}$ & $\begin{array}{l}-48034 \cdot 51 \\
-48180 \cdot 69 \\
-48147 \cdot 24\end{array}$ & $\begin{array}{l}(2-1) 97 \cdot 82^{* *} \\
(3-2) 15 \cdot 51^{\text {n.s }} \\
-\end{array}$ \\
\hline
\end{tabular}

† Models: LEGka.kpe_r or LEGka.kpe_1, corresponding the functions Legendre polynomials (LEG), corresponding to the order of the covariance function for additive genetic $(\mathrm{ka})$ and permanent environmental ( $\mathrm{kpe}$ ) effects and to the residual variance structure of variances modeled by a step function ( $\mathrm{r}$ ) assuming $\mathrm{n}$ variance classes or variance homogeneity (1)

$\neq$ Verisimilitude ratio test among the hierarchical models. ${ }^{* *} P<0,01 ;{ }^{\text {n.s }}$ not significant

estimated for the traits. The information criteria can be represented as:

$\mathrm{AIC}=-2 \log L+2 p$

$\mathrm{BIC}=-2 \log L+p \log (N-r(X))$

where $p$ is the number of parameters estimated, $N$ is the number of data, $r(\mathrm{X})$ the rank of the coefficient matrix of fixed effect in the model of analysis, and $\log L$ is the restricted maximum log-likelihood function (Wolfinger, 1993).

\section{Results and Discussion}

The average test-day milk yields (Table 1 ) show a typical lactation curve for buffaloes, starting at $8.24 \mathrm{~kg}$, with increased production until a peak on the second test day
$(8 \cdot 87 \mathrm{~kg})$ and subsequent decline until the end of lactation $(4.9 \mathrm{~kg})$. For the yields of fat and protein, the test-day averages were 0.40 and $0.24 \mathrm{~kg}$, with SD of 0.14 and $0.08 \mathrm{~kg}$ and coefficients of variation of 35.40 and $35.32 \%$, respectively. As can be observed in Table 1 , there was an increase in production in the initial lactation phase $(0.40 \mathrm{~kg}$ for fat and $0.23 \mathrm{~kg}$ for protein) until the third month $(0.49 \mathrm{~kg}$ for fat and $0.27 \mathrm{~kg}$ for protein). These yields both declined as of the fourth month, with the increase in the number of lactation days until the end $(0.30 \mathrm{~kg}$ for fat and $0.22 \mathrm{~kg}$ for protein). There was greater variation in the fat and protein production at the start and end of lactation.

The best fit for the residual variance (Table 2) shows increases in the log-likelihood, significant $(P<0 \cdot 01)$ according to the likelihood ratio test (LRT), with an increasing number of heterogeneous classes. According to the criteria 
Table 3. Number of estimated parameters $(\mathrm{N})$ ), log likelihood function (Log L), Akaike's information criterion (AIC), Schwarz Bayesian information criterion (BIC) and likelihood ratio test (LRT) for the models used comparing the number of classes for the residual variance of milk, fat and protein yields

\begin{tabular}{|c|c|c|c|c|c|}
\hline Modelt & $\mathrm{N}$ & $\log L$ & $\mathrm{AIC}$ & $\mathrm{BIC}$ & LRT‡ \\
\hline $\begin{array}{l}\text { Milk } \\
\text { (1) LEG3,4_4 } \\
\text { (2) LEG3,5_4 } \\
\text { (3) LEG3,6_4 } \\
\text { (4) LEG4,4_4 } \\
\text { (5) LEG4,5_4 } \\
\text { (6) LEG4,6_4 } \\
\text { (7) LEG5,5_4 } \\
\text { (8) LEG5,6_4 }\end{array}$ & $\begin{array}{l}20 \\
25 \\
31 \\
24 \\
29 \\
35 \\
34 \\
40\end{array}$ & $\begin{array}{l}-8000 \cdot 44 \\
-7991 \cdot 65 \\
-7977 \cdot 99 \\
-7981 \cdot 55 \\
-7973 \cdot 01 \\
-7959 \cdot 58 \\
-7972 \cdot 52 \\
-7958 \cdot 99\end{array}$ & $\begin{array}{l}16040 \cdot 89 \\
16033 \cdot 29 \\
16017 \cdot 99 \\
16011 \cdot 09 \\
16004 \cdot 01 \\
\mathbf{1 5 9 8 9 \cdot 1 6} \S \\
16013 \cdot 03 \\
15997 \cdot 97\end{array}$ & $\begin{array}{l}\mathbf{1 6 1 8 5} \cdot \mathbf{6 2} \S \\
16214 \cdot 21 \\
16242 \cdot 33 \\
16184 \cdot 78 \S \\
16213 \cdot 88 \\
16242 \cdot 45 \\
16259 \cdot 08 \\
16287 \cdot 45\end{array}$ & $\begin{array}{l}(2-1) 8 \cdot 79^{\text {n.s }} \\
(3-2) 13 \cdot 65^{*} \\
- \\
(5-4) 9^{n . s} \\
(6-5) 13 \cdot 43^{*} \\
- \\
(8-7) 6^{*} \\
-\end{array}$ \\
\hline $\begin{array}{l}\text { Fat } \\
\text { (1) LEG3,4_4 } \\
\text { (2) LEG3,5_4 } \\
\text { (3) LEG3,6_4 } \\
\text { (4) LEG4,4_4 } \\
\text { (5) LEG4,5_4 } \\
\text { (6) LEG4,6_4 } \\
\text { (7) LEG5,5_4 } \\
\text { (8) LEG5,6_4 }\end{array}$ & $\begin{array}{l}20 \\
25 \\
31 \\
24 \\
29 \\
35 \\
34 \\
40\end{array}$ & $\begin{array}{l}19581 \cdot 16 \\
19606 \cdot 42 \\
19614 \cdot 96 \\
19592 \cdot 13 \\
19616 \cdot 27 \\
19624 \cdot 53 \\
19620 \cdot 09 \\
19628 \cdot 22\end{array}$ & $\begin{array}{l}-39122 \cdot 33 \\
-39162 \cdot 85 \\
-39167 \cdot 91 \\
-39136 \cdot 26 \\
-39174 \cdot 54 \\
-39179 \cdot 06 \S \\
-39172 \cdot 18 \\
-39176 \cdot 44\end{array}$ & $\begin{array}{l}-38978 \cdot 10 \\
-\mathbf{3 8 9 8 2 \cdot 5 7} \\
-38944 \cdot 37 \\
-38963 \cdot 19 \\
-38965 \cdot 42 \S \\
-38926 \cdot 67 \\
-38927 \cdot 01 \\
-38887 \cdot 99\end{array}$ & $\begin{array}{l}(2-1) 25 \cdot 26^{* *} \\
(3-2) 8 \cdot 53^{\text {n.s }} \\
- \\
(5-4) 24 \cdot 14^{* *} \\
(6-5) 8 \cdot 26^{\text {n.s }} \\
- \\
(8-7) 8 \cdot 13^{\text {n.s }} \\
-\end{array}$ \\
\hline $\begin{array}{l}\text { Protein } \\
\text { (1) LEG3,4_3 } \\
\text { (2) LEG3,5_3 } \\
\text { (3) LEG3,6_3 } \\
\text { (4) LEG4,4_3 } \\
\text { (5) LEG4,5_3 } \\
\text { (6) LEG4,6_3 } \\
\text { (7) LEG5,5_3 } \\
\text { (8) LEG5,6_3 }\end{array}$ & $\begin{array}{l}19 \\
24 \\
30 \\
23 \\
28 \\
34 \\
33 \\
39\end{array}$ & $\begin{array}{l}24169 \cdot 54 \\
24180 \cdot 54 \\
24201 \cdot 41 \\
24179 \cdot 64 \\
24190 \cdot 28 \\
24210 \cdot 53 \\
24192 \cdot 96 \\
24212 \cdot 95\end{array}$ & $\begin{array}{l}-48301 \cdot 08 \\
-48312 \cdot 71 \\
-48342 \cdot 81 \\
-48313 \cdot 27 \\
-48324 \cdot 55 \\
-\mathbf{4 8 3 5 3 \cdot 0 6} \$ \\
-48319 \cdot 91 \\
-48347 \cdot 89\end{array}$ & $\begin{array}{l}-\mathbf{4 8 1 6 3 \cdot 8 9} \\
-48139 \cdot 65 \\
-48126 \cdot 48 \\
-48147 \cdot 41 \S \\
-48102 \cdot 64 \\
-48107 \cdot 88 \\
-48081 \cdot 94 \\
-48066 \cdot 66\end{array}$ & $\begin{array}{l}(2-1) 10 \cdot 99^{\text {n.s }} \\
(3-2) 20 \cdot 87^{* *} \\
- \\
(5-4) 10 \cdot 64^{\text {n.s }} \\
(6-5) 20 \cdot 26^{* *} \\
- \\
(8-7) 19 \cdot 99^{* *} \\
-\end{array}$ \\
\hline
\end{tabular}

† Models: LEGka.kpe_r, corresponding the functions Legendre polynomials (LEG), corresponding to the order of the covariance function for additive genetic (ka) and permanent environmental (kpe) effects and to the residual variance structure of variances modeled by a step function ( $\mathrm{r}$ ) assuming 3 or 4 variance classes $\ddagger$ Verisimilitude ratio test between the hierarchical models. ${ }^{* *} P<0 \cdot 01{ }^{\text {,.s.s }}$ not significant

§Indicates the best model based on the AIC and BIC

used (AIC and BIC) to assess the goodness of fit, the model considering homogeneity of the residual variances was inadequate. This indicated that the residual variances behaved differently during the lactation period, making it necessary to consider a heterogeneous variance structure for the residuals. The heterogeneous residual variances can be attributed to factors such as the stage of pregnancy, body condition and duration of the lactation interval, among others, since these factors are not easily incorporated in analytic models owing to the lack of information about them (Rekaya et al. 2000; El Faro \& Albuquerque, 2003).

For the traits under study, the models with 10 residual classes should be applied, but for production of milk and fat, based on the LEG3,3_4 model, and for production of protein based on the LEG3,3_3 model, the changes in the log $L$ were small in magnitude and not significant by the LRT $(P>0 \cdot 01)$. This can indicate that for the milk and fat yield models, four residual classes would be sufficient and three classes would be enough for protein yield to obtain a good residual variance fit. This would avoid using over-parameterized models, which in general present parameter estimation problems (Bignardi et al. 2009; Sesana et al. 2010).

Random regression models by means of Legendre polynomial functions require definition of the most appropriate order for each random effect considered in the model. For the milk, fat and protein output (Table 3), in general there was an improvement in the $\log \mathrm{L}$ criterion $(P>0 \cdot 01$, by the LRT) and AIC by increasing the order of adjustment from three to four for the additive genetic variance part associated with order six for the permanent environmental variance. The $\mathrm{BIC}$, more rigorous because of the parameterization, indicated LEG3,4_4, LEG3,5_4 and LEG3,4_3 as the best models for milk, fat and protein yield, respectively. Therefore these are the most suitable models to describe the variation of milk, fat and protein production during lactation. Pool et al. (2000) reported that the lactation curves can be modelled with enough precision using a third-order Legendre polynomial for the additive genetic component and a fourth-order one for the permanent environmental component. Lopez-Romero \& Carabaño (2003) also reported that Legendre polynomials of low order for the 
Table 4. Percentage of variance explained by eigenvalues of the matrix of random regression coefficients for additive genetic and permanent environmental effects for selected models

Random regression coefficient

Trait

Additive

Permanent environmental

Additive

Permanent environmental

Additive

Permanent environmental

\begin{tabular}{|c|c|c|c|c|}
\hline \multicolumn{5}{|c|}{ Random regression coefficient } \\
\hline 1 & 2 & 3 & 4 & 5 \\
\hline \multicolumn{5}{|c|}{ Milk LEG3,4_4 and (LEG4,4_4) } \\
\hline $86 \cdot 72(84 \cdot 05)$ & $10 \cdot 19(10 \cdot 43)$ & $3.09(5 \cdot 52)$ & $-(0 \cdot 00)$ & - \\
\hline $82 \cdot 75(84 \cdot 75)$ & $10 \cdot 44(10 \cdot 55)$ & $5 \cdot 18(3 \cdot 70)$ & $1.63(1.00)$ & - \\
\hline \multicolumn{5}{|c|}{ Fat LEG3,5_4 and (LEG4,5_4) } \\
\hline $83 \cdot 34(83 \cdot 04)$ & $11.96(12 \cdot 07)$ & $\overline{4} \cdot 71(4 \cdot 89)$ & $-(0 \cdot 00)$ & - \\
\hline $79.52(79.92)$ & $13 \cdot 79(13 \cdot 87)$ & $3 \cdot 71(4 \cdot 36)$ & $2 \cdot 28(1 \cdot 26)$ & $0.71(0.59)$ \\
\hline \multicolumn{5}{|c|}{ Protein LEG3,4_3 and (LEG4,4_3) } \\
\hline $81 \cdot 47(80 \cdot 26)$ & $13 \cdot 35(14 \cdot 23)$ & $5 \cdot 18(5 \cdot 51)$ & $-(0 \cdot 00)$ & - \\
\hline $79 \cdot 12(79 \cdot 80)$ & $13 \cdot 69(13 \cdot 72)$ & $5 \cdot 04(5 \cdot 66)$ & $2 \cdot 15(0 \cdot 83)$ & - \\
\hline
\end{tabular}
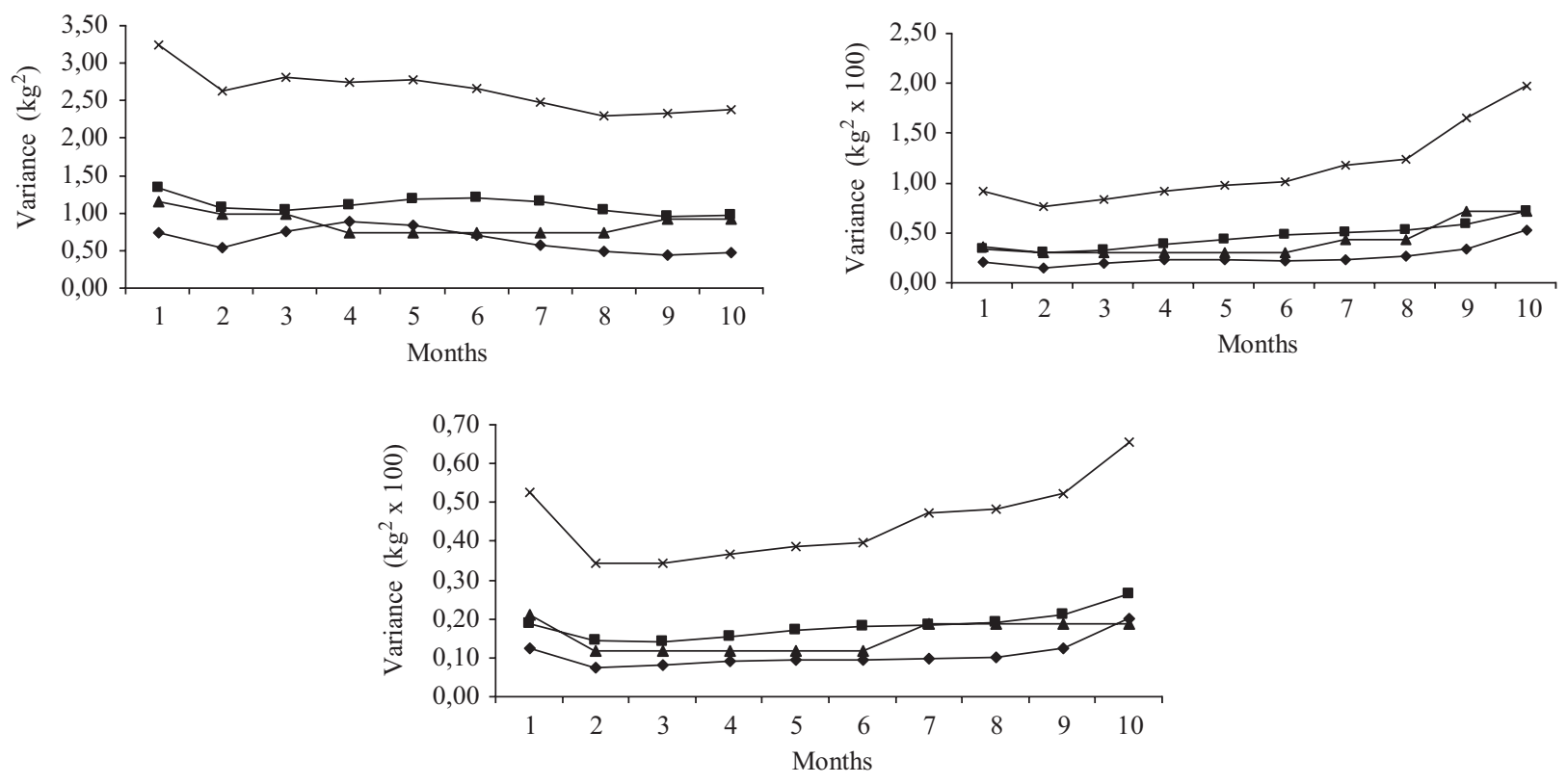

Fig. 1. Estimates of additive variance permanent environment residual $(\boldsymbol{\Delta})$ and phenotypic (x), for test-day milk yield per month, obtained with the LEG3,4_4 (above left), fat yield obtained with the LEG3, 5_4 (above right) and protein yield obtained with the LEG3,4_3 (below).

additive and permanent environmental variances can be most adequate.

Percentage of variance explained by eigenvalues associated with the random regression coefficients matrix for the additive genetic and permanent environmental effects, for the two best models for each of the traits according to the BIC, are presented in Table 4. The models of lower order are sufficient to capture all the variation of the trait, with a fourth coefficient for the additive part being associated with a zero eigenvalue, unlike for the permanent environmental effect. The eigenvalues analysed show that the first was responsible for over $79 \%$ of the variance of the data in the models adjusted to the traits under study. The variability of the data for the additive genetic and permanent environmental effects was mainly explained by the first two eigenvalues (more than 90\%). According to the results of the eigenvalues, the dimension of the two random effects could be reduced without loss of information, in disagreement with the $\log L$ and Akaike information criteria for the additive genetic and permanent environmental effects and in agreement with the Bayesian information criterion for the additive genetic effect. However, Legarra et al. (2004) indicated that one must consider the fact that reducing the dimensionality resulting from eliminating eigenvalues near zero is not advisable in all cases, since adopting this criterion can result in an over-simplistic or inadequate model.

The estimates of the genetic additive, permanent environmental, residual and phenotypic variances for the yields of milk (model LEG3,4_4), fat (model LEG3,5_4) and protein (model LEG3,4_3) on the test day are presented in Fig. 1. 

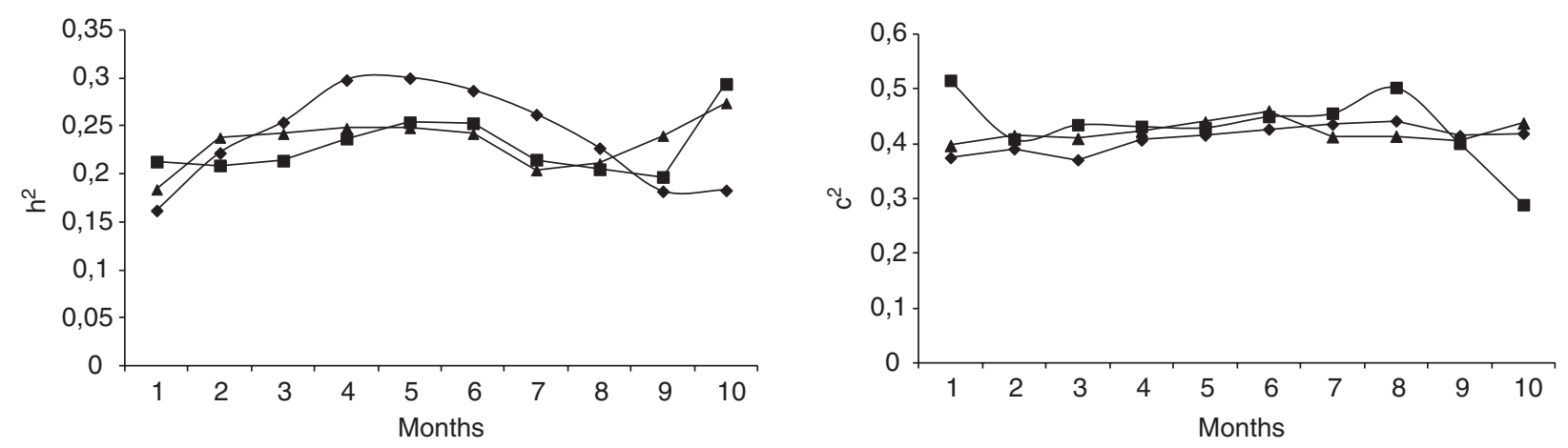

Fig. 2. Estimates of heritability $\left(h^{2}-\right.$ left) and proportion of phenotypic variance due to permanent environmental $\left(c^{2}-\right.$ right $)$ for the milk yield

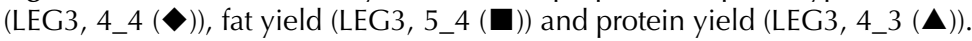

Table 5. Estimated genetic correlations (above diagonal) and phenotypic correlations (below diagonal) between monthly test-day observations for milk yield (LEG3,4_4), fat yield (LEG3,5_4) and protein yield (LEG3,4_3)

\begin{tabular}{|c|c|c|c|c|c|c|c|c|c|c|c|}
\hline & $\mathrm{Ct}$ & 1 & 2 & 3 & 4 & 5 & 6 & 7 & 8 & 9 & 10 \\
\hline \multirow[t]{10}{*}{ Milk } & 1 & - & 0.94 & $0 \cdot 83$ & $0 \cdot 73$ & 0.65 & $0 \cdot 59$ & 0.53 & $0 \cdot 47$ & $0 \cdot 36$ & $0 \cdot 18$ \\
\hline & 2 & $0 \cdot 54$ & - & 0.97 & 0.92 & $0 \cdot 87$ & $0 \cdot 82$ & 0.77 & 0.69 & 0.53 & $0 \cdot 24$ \\
\hline & 3 & 0.44 & $0 \cdot 60$ & - & 0.99 & 0.96 & 0.93 & $0 \cdot 88$ & $0 \cdot 80$ & 0.62 & $0 \cdot 29$ \\
\hline & 4 & $0 \cdot 41$ & $0 \cdot 59$ & 0.67 & - & 0.99 & 0.97 & 0.94 & $0 \cdot 86$ & 0.68 & 0.33 \\
\hline & 5 & $0 \cdot 38$ & $0 \cdot 55$ & $0 \cdot 64$ & $0 \cdot 71$ & - & 0.99 & 0.97 & 0.91 & $0 \cdot 74$ & 0.39 \\
\hline & 6 & $0 \cdot 36$ & $0 \cdot 51$ & 0.59 & 0.67 & 0.71 & - & 0.99 & 0.94 & $0 \cdot 80$ & 0.46 \\
\hline & 7 & $0 \cdot 35$ & $0 \cdot 47$ & $0 \cdot 54$ & $0 \cdot 62$ & 0.67 & $0 \cdot 70$ & - & 0.98 & $0 \cdot 87$ & 0.57 \\
\hline & 8 & $0 \cdot 32$ & $0 \cdot 42$ & 0.49 & 0.57 & 0.62 & 0.66 & 0.68 & - & 0.95 & 0.72 \\
\hline & 9 & $0 \cdot 24$ & $0 \cdot 36$ & $0 \cdot 42$ & $0 \cdot 48$ & 0.52 & $0 \cdot 55$ & $0 \cdot 58$ & $0 \cdot 61$ & - & 0.90 \\
\hline & 10 & $0 \cdot 12$ & $0 \cdot 27$ & $0 \cdot 35$ & $0 \cdot 39$ & $0 \cdot 40$ & $0 \cdot 40$ & $0 \cdot 41$ & $0 \cdot 46$ & 0.53 & - \\
\hline \multirow[t]{10}{*}{ Fat } & 1 & - & 0.92 & 0.75 & 0.62 & 0.55 & $0 \cdot 53$ & 0.55 & $0 \cdot 59$ & $0 \cdot 61$ & 0.60 \\
\hline & 2 & $0 \cdot 51$ & - & 0.95 & $0 \cdot 88$ & $0 \cdot 83$ & $0 \cdot 80$ & 0.79 & 0.75 & 0.66 & 0.54 \\
\hline & 3 & $0 \cdot 38$ & $0 \cdot 60$ & - & 0.98 & 0.96 & 0.93 & $0 \cdot 89$ & $0 \cdot 81$ & 0.66 & 0.47 \\
\hline & 4 & $0 \cdot 33$ & $0 \cdot 56$ & $0 \cdot 64$ & - & 0.99 & 0.97 & 0.93 & $0 \cdot 83$ & 0.66 & 0.44 \\
\hline & 5 & $0 \cdot 31$ & $0 \cdot 53$ & 0.62 & 0.67 & - & 0.99 & 0.96 & $0 \cdot 86$ & 0.69 & 0.47 \\
\hline & 6 & $0 \cdot 28$ & $0 \cdot 50$ & 0.59 & $0 \cdot 64$ & 0.68 & - & 0.99 & 0.91 & $0 \cdot 76$ & 0.55 \\
\hline & 7 & $0 \cdot 23$ & $0 \cdot 45$ & 0.53 & 0.57 & 0.62 & 0.66 & - & 0.97 & $0 \cdot 86$ & 0.69 \\
\hline & 8 & $0 \cdot 18$ & $0 \cdot 41$ & $0 \cdot 48$ & $0 \cdot 51$ & 0.55 & 0.63 & 0.67 & - & 0.96 & $0 \cdot 84$ \\
\hline & 9 & $0 \cdot 14$ & $0 \cdot 34$ & $0 \cdot 39$ & $0 \cdot 40$ & 0.43 & $0 \cdot 50$ & $0 \cdot 56$ & 0.63 & - & 0.96 \\
\hline & 10 & $0 \cdot 16$ & $0 \cdot 29$ & $0 \cdot 31$ & $0 \cdot 31$ & $0 \cdot 32$ & $0 \cdot 37$ & $0 \cdot 42$ & $0 \cdot 50$ & $0 \cdot 53$ & - \\
\hline \multirow[t]{10}{*}{ Protein } & 1 & - & 0.94 & 0.82 & $0 \cdot 70$ & $0 \cdot 61$ & $0 \cdot 56$ & 0.54 & 0.53 & $0 \cdot 50$ & 0.46 \\
\hline & 2 & $0 \cdot 56$ & - & 0.96 & $0 \cdot 89$ & $0 \cdot 83$ & $0 \cdot 78$ & 0.74 & 0.67 & 0.57 & 0.44 \\
\hline & 3 & $0 \cdot 46$ & 0.62 & - & 0.98 & 0.95 & 0.91 & 0.85 & 0.75 & $0 \cdot 60$ & 0.41 \\
\hline & 4 & $0 \cdot 38$ & 0.57 & 0.65 & - & 0.99 & 0.96 & 0.91 & $0 \cdot 81$ & 0.63 & 0.42 \\
\hline & 5 & $0 \cdot 34$ & 0.53 & 0.62 & 0.67 & - & 0.99 & 0.95 & $0 \cdot 85$ & 0.68 & 0.46 \\
\hline & 6 & $0 \cdot 32$ & $0 \cdot 49$ & 0.58 & 0.64 & 0.68 & - & 0.98 & 0.91 & 0.76 & 0.56 \\
\hline & 7 & $0 \cdot 28$ & $0 \cdot 42$ & $0 \cdot 50$ & 0.56 & $0 \cdot 61$ & 0.65 & - & 0.97 & $0 \cdot 86$ & 0.69 \\
\hline & 8 & $0 \cdot 27$ & $0 \cdot 38$ & 0.45 & $0 \cdot 51$ & 0.56 & $0 \cdot 61$ & $0 \cdot 61$ & - & 0.96 & 0.84 \\
\hline & 9 & $0 \cdot 24$ & $0 \cdot 33$ & $0 \cdot 38$ & $0 \cdot 43$ & 0.48 & 0.53 & 0.55 & $0 \cdot 61$ & - & 0.96 \\
\hline & 10 & $0 \cdot 17$ & $0 \cdot 25$ & $0 \cdot 29$ & $0 \cdot 31$ & $0 \cdot 34$ & $0 \cdot 39$ & 0.42 & $0 \cdot 51$ & 0.63 & - \\
\hline
\end{tabular}

+Monthly test day

In the estimates of the additive variance for milk output, there was an increase from the start until the fourth month, after which the yield declined until the end of lactation. The estimate of the permanent environmental variance remained practically constant during the lactation period and was greater than the additive and residual variances. The residual variance estimates declined from the fourth to the eighth month of lactation.

For the fat and protein yields (Fig. 1), the additive genetic variances presented the same tendency as the phenotypic variance, with higher values at the end of lactation. These higher estimates of the constituents might have been due to 
the number of data readings obtained or to the higher levels of fat and protein found at the end of lactation. In general, the trends of the additive and permanent environmental variances throughout the lactation period obtained in this study (for the three traits) are comparable to those found by Gengler et al. (1997), Silvestre et al. (2005), Muir et al. (2007) and De Groot et al. (2007) all of whom reported higher additive and permanent environmental variances at the start and end of lactation for milk as well as fat and protein yield.

Figure 2 shows the heritability $\left(h^{2}\right)$ and proportion of the phenotypic variance corresponding to the permanent environmental variance. The estimates of heritability for milk yield fluctuated between $0 \cdot 16 \pm 0 \cdot 05$ and $0 \cdot 29 \pm 0 \cdot 05$ and were greatest in the fourth and sixth months of measurement.

This result differs from those found by Sesana et al. (2010) and Breda et al. (2010) in which the estimates were higher at the extremes of the lactation curve. This can be attributed to the fact that these authors utilized weekly tests. However, the heritability estimates were near those found by Aspilcueta et al. $(2010 b, c)$ who used finite dimensional models. The heritability estimates for production of fat and protein (Fig. 2) showed a similar trend during the lactation, with a sharp increase at the end of this phase. These results follow the same trend observed in the literature by the majority of researchers in dairy cattle (Gengler et al. 1997; Silvestre et al. 2005, De Groot et al. 2007; Muir et al. 2007). The heritability estimates for fat production varied from $0 \cdot 20 \pm 0 \cdot 05$ (ninth month) to $0 \cdot 30 \pm 0 \cdot 08$ (tenth month). However, the heritability estimates for protein varied from $0 \cdot 18 \pm 0 \cdot 06$ (first month) to $0 \cdot 27 \pm 0 \cdot 08$ (tenth month). These results are near the estimates obtained by the majority of researchers in dairy cattle using random regression models (Gengler et al. 1997; Liu et al. 2000; De Roos et al. 2004; Muir et al. 2007). Aspilcueta et al. (2010c) used finite dimensional models with monthly data on fat and protein yield of buffaloes and found heritability estimates of lower magnitude than those found in the present study.

The fractions of phenotypic variances referring to the permanent environmental variance of the traits in the present study were greater than the heritability estimates throughout the lactation period, a similar finding to that of El Faro \& Albuquerque (2003) in dairy cattle.

The estimates of the genetic and phenotypic correlations for production of milk, fat and protein are presented in Table 5. The genetic correlations for milk production on the test day ranged from $0 \cdot 18 \pm 0 \cdot 130$ to $0 \cdot 99 \pm 0 \cdot 002$, and were higher the nearer the test days were to each other, declining as the interval between them increased. Among the test days in the middle of the lactation period, these genetic correlations were the highest, near one. This pattern is close to those reported by Sesana et al. (2010) and Breda et al. (2010). Nevertheless, those authors found negative genetic correlation estimates between the first and last test days. Aspilcueta et al. $(2010 \mathrm{~b}, \mathrm{c})$ reported higher estimates, probably owing to the finite dimensional model methodology.
The estimates of the genetic correlations (Table 5) for the fat and protein yields during the lactation period ranged from $0.44 \pm 0.080$ to $0.99 \pm 0.004$ and $0.41 \pm 0.080$ to $0 \cdot 99 \pm 0 \cdot 004$, respectively. Most of the estimated correlations were high, approaching one. It can also be seen that the estimates were higher when the test-day fat and protein yields were nearer to each other. Aspilcueta et al. (2010c) reported similar estimates using a finite dimensional model for fat and protein.

For the traits under investigation, the lowest genetic correlation estimates occurred between the yield in the first month and the other test-day months, probably owing to the difficulty of modelling the initial lactation tests, because during this phase the animals suffer post-partum stress and also have negative energy balance.

The phenotypic correlation estimates (Table 5) between the yields for the traits under study were lower as the interval between the test days increased. In general the phenotypic correlation estimates were lower than the genetic ones. This same pattern was reported by Aspilcueta et al. (2010c).

\section{Conclusions}

Random regression models employing Legendre polynomials were efficient to describe the genetic variation for test-day yield of milk, fat and protein among buffaloes.

The heritability estimates of the traits were moderate, which can help in the process of selecting animals to obtain genetic gains. The estimates of the genetic correlations were high among the test days, indicating that by either selection criterion, indirect genetic gains can be expected throughout the lactation curve.

This study was supported by the State of São Paulo Research Foundation (Fapesp) and the National Council of Technological and Scientific Development (CNPq). The authors thank the Brazilian Association of Breeders of Buffaloes (ABCB) for providing the pedigree and phenotypic data.

\section{References}

Aspilcueta RB, Araujo Neto FR, Baldi F, Bignardi AB, Albuquerque LG \& Tonhati H 2010a Genetic parameters for buffalo milk yield and milk quality traits using Bayesian inference. Journal of Dairy Science 93 2195-2201

Aspilcueta RB, Bignardi AB, Seno LO, Camargo GM, Muñoz-Berrocal M, Albuquerque LG, Di Palo R \& Tonhati H 2010b Genetic parameters for milk yield analyzed by test day models in Murrah buffaloes in Brazil. Italian Journal of Animal Science 9(2) 179-182

Aspilcueta RB, Sesana RC, Muñoz-Berrocal M, Seno LO, Bignardi AB, El Faro L, Albuquerque LG, Camargo GM \& Tonhati H 2010c Genetic parameters for milk, fat and protein yields in Murrah buffaloes (Bubalus bubalis Artiodactyla, Bovidae). Genetics and Molecular Biology 33 71-77

Bignardi AB, El Faro L, Albuquerque LG, Cardoso VL \& Machado PF 2009 Random regression models to estimate testday milk yield genetic parameters Holstein cows in southeastern Brazil. Livestock Production Science $1231-7$ 
Breda FC, Albuquerque LG, Euclydes RF, Bignardi AB, Baldi F, Torres RA, Barbosa L \& Tonhati H 2010 Estimation of genetic parameters for milk yield in Murrah buffaloes by Bayesian inference. Journal of Dairy Science 93 784-791

De Groot BJ, Keown JF, Van Vleck LD \& Kachman SD 2007 Estimates of genetic parameters for Holstein cows for testday yield traits with a random regression cubic spline model. Genetics and Molecular Research 6 434-444

De Roos APW, Harbers AGF \& Jong G 2004 Random herd curves in a test-day model for milk, fat and protein production of dairy cattle in the Netherlands. Journal of Dairy Science 87 2693-2701

El Faro L \& Albuquerque LG 2003 Utilização de modelos de regressão aleatória para a produção de leite no dia do controle, com diferentes estruturas de variâncias residuais. Revista Brasileira de Zootecnia 32(5) $1104-1113$

Gengler N, Tijini A, Wiggans GR \& Philpot JC 1997 Estimation of (co) variance components of test day yields for U.S. Holsteins. Proceeding of the 1997 Interbull meeting, Vienna, Austria, August 28-29 1997 Interbull Bull 16 39-42 Avaliable at http://www-interbull.slu.se/bulletins/ bulletin16/Gengler.pdf

Jakobsen JH, Madsen P, Jensen J, Pedersen J, Christensen LG \& Sorensen DA 2002a Genetic parameters for milk production and persistency for Danish Holsteins estimated in random regression models using REML. Journal of Dairy Science 85(6) 1607-1616

Jakobsen JH, Madsen P \& Pedersen J 2002b Multivariate covariance functions for test day production in Danish breeds. Proceeding of the 2002 Interbull Meeting, Interlaken, Switzerland, May 26-27 2002 Interbull Bull 29 95-102 Available at http://www-interbull.slu.se/ bulletins/bulletin29//akobsen.pdf

Legarra A, Misztal I \& Bertrand JK 2004 Constructing covariance functions for random regression models for growth in Gelbvieh beef cattle. Journal Animal Science 82 1564-1571

Liu Z, Reinhardt F \& Reents R 2000 Estimating parameters of a random regression test day model for first three lactation milk production traits using the covariance function approach. Proceeding of the 2000 Interbull meeting, Interlaken, Switzerland, May 14-15 2000 Interbull Bull 25 74-80 Available at http://www-interbull.slu.se/bulletins/bulletin25/liu. pdf
López-Romero P \& Carabaño MJ 2003 Comparing alternative random regression models to analyse first-lactation daily milk yield data in Holstein-Friesian cattle. Livestock Production Science $\mathbf{8 2}$ 81-86

Malhado CH, Ramos A, Carneiro P, Souza J \& Piccinin A 2007 Genetic and phenotypic parameters for milk production of Murrah buffaloes. Brazilian Journal Animal Science 37 376-379

Meyer K 2006 "WOMBAT"-Digging deep for quantitative genetic analyses by restricted maximum likelihood. CD-ROM Eighth World Congress on Genetic Applied to Livestock Production, Proceedings. ..Communication No. 27-14.

Muir BL, Kistemaker G, Jamrozik J \& Canavesci F 2007 Genetic parameters for a multiple-trait multiple-lactation random regression test-day model in Italian Holsteins. Journal of Dairy Science 90 1564-1574

Pool MH, Janss LLG \& Meuwissen THE 2000 Genetic parameters of Legendre polynomials for first parity lactation curves. Journal of Dairy Science 83 2640-2649

Rekaya R, Carabaño MJ \& Toro MA 2000 Assessment of heterogeneity of residual variance using changing points techniques. Genetics Selection Evolution 32 339-346

Schaeffer LR \& Jamrozik J 2008 Random regression models: a longitudinal perspective. Journal of Animal Breeding and Genetics 125 145-146

Seno LO, Cardoso VL \& Tonhati H 2007 Valores econômicos para as características de produção de leite de búfalas no Estado de São Paulo. Revista Brasileira de Zootecnia 36 2016-2022

Sesana RC, Bignardi AB, Aspilcueta RA, El Faro L, Baldi F, Albuquerque LG \& Tonhati H 2010 Random regression models to estimate genetic parameters for test-day milk yield in Brazilian Murrah buffaloes. Journal of Animal Breeding and Genetics 127 369-376

Silvestre AM, Petim-Batista F \& Colaço J 2005 Genetic parameters estimates of Portuguese dairy cows for milk, fat and protein using a Spline test-day model. Journal Dairy Science $\mathbf{8 8} 1225-1230$

Tonhati H, Baruselli PS, Oliveira JFS, Vasconcellos BF \& Toledo LM 1996 Calving season, peak of lactation and milk production of the buffalo in Ribeira Valley, São Paulo State Brazil. Rev. Bubalus Bubalis, Salerno, Italia 3 63-67

Wolfinger R 1993 Covariance structure selection in general mixed models. Communications in Statistics 22(4) 1079-1106 